\title{
A Survey of the Inadequacies of Oral English Teaching in Developing Areas of Zhejiang Province
}

\author{
Wei Xiong \\ Zhejiang Ocean University, Zhoushan, China
}

\begin{abstract}
Affected by exam-oriented education, many teachers and students pay more attention to written knowledge in the process of English learning in junior high schools in Zhejiang Province. Students' ability of oral English is not as good as written expression, especially in areas where economic development is relatively slow. This paper aims to find out the factors that affect the oral communication ability of junior high school students in Zhoushan through the field investigation of Ningbo and Zhoushan. It can provide direction and reference for improving students' oral English ability in economically underdeveloped areas in the future.
\end{abstract}

Index Terms - developed areas, developing areas, oral English, Zhejiang Province

\section{INTRODUCTION}

Foreign Language education plays an increasingly important role in the development of social economy in our country. What's more, English education in primary and secondary schools in China has received extensive attention, and the reform of English Curriculum in primary and secondary schools has also become the focus of social attention. Therefore, how to take effective English teaching methods to improve students' learning ability has become the educators' common concern.

As we all know, though more attention has been paid to English, oral English is still at the disadvantage under the education system of China, especially in some developing areas. Even as economically advanced province, Zhejiang Province also inevitably has the same problem. The author's investigation aims to find the differences of oral English teaching in junior middle schools between developed areas and developing areas in Zhejiang Province, in order to provide reference for developed areas in Zhejiang to improve the quality of oral English teaching and balance the ability of oral English between students from developing and developed areas. With the limitation of time, energy and fund, the author's team chooses Ningbo and Zhoushan as respondents, which can represent developed areas and developing areas respectively.

\section{LITERATURE REVIEW}

\section{A. Several Important Definitions}

Economically developed areas mainly refer to regions where the Per Capita GNP (Gross National Product), Per Capita Government Revenue and Per Capita Net Income of Farmers are all higher than the average level. And developing areas refer to those areas that have certain economic strength and potential but still lag behind the developed regions to a certain extent, have unbalanced development of productive forces and are underdeveloped in science and technology.

The New First-tier City, Second-tier City, Third-tier City and Four-tier City are selected by CBNweekly in 2018. The selection divided cities into different tier according to a series of indicators such as economic, political and academic resources. The New First-tier City refers to those municipalities directly under the central government, have a strong economic foundation, a large middle class and considerable political resources. Four-tier City refers to those medium-sized cities with relatively ordinary urban scale, economic and social development level and transportation construction.

Education informatization is an important part of national informatization. Education Informatization has two meanings: one is to integrate the improvement of information literacy into the education objective and cultivate talents adapted to the information society. Second is to effectively apply information technology means in teaching and research and pay attention to the development and utilization of education information resources. The writer chooses the second definition in this paper.

\section{B. Previous Studies on Education in Developed Areas and Developing Areas}

It is reported that there is a big gap of educational level between developed areas and developing areas and that the ability to speak English of different students in different areas varies greatly. Some researchers have done some related researches with much experience to gain and some limitations. 
As for the previous studies on education in developed areas and developing areas, the writer collected related studies on teachers' teaching level and educational informatization.

The writer argues that many years of teaching practice shows that the role that teachers play in students' ability of oral English is still rather vital. Educationalist Suhomlinsky once said: "Teachers' accomplishment of teaching language to a great extent determines students' mental work efficiency in class."However, it is believed that education in developing areas is still the weakest part in the development of education career in China. And the low quality of teachers is still a main shortcoming that restricts the development of education in developing areas. In developing areas, strengthening the construction and management of teachers is definitely urgent and important (Zhang, 2016). And the writer manages to conclude three main deficiencies of junior middle school English teachers in developing areas in this thesis.

One of the purposes of English teaching is to promote the cultivation of students' thinking ability, help them build up confidence and be able to skillfully use English for communication. However, traditional oral English teaching methods and techniques lack a good English context, which is not conducive to students' oral English learning. Luckily, Education Informatization now can be used to solve this problem. In Bai Yingjie's (2012) thesis, multimedia technology plays the most important role, which has variability, intuition, knowledge and authenticity. While in Zhejiang Province, which in general is a developing province, the writer finds that things are different.

\section{Previous Studies on Students' Oral English}

There is a big gap of English acquisition between developed areas and developing areas and that the ability to speak English of different students in different areas varies greatly. It must come down to some reasons and most scholars studied in the following three aspects: influence factor, problem and teaching strategy.

Firstly, some influencing factors of oral English are discussed by many scholars in different lights. Among all the studies and theories, Hawkes's idea concluded best. It is found that the students' oral output has two factors: external factors and internal factors. The external factors include the controllable emotion and uncontrollable intelligence. And the internal factors include the controllable emotion and uncontrollable intelligence (Hawkes, 2010).

And it is believed there are mainly four problems existing oral English teaching in the junior middle school including ignoring phonetic teaching, lacking phonetic practice, lacking listening practice and lacking language environment. In daily English teaching, teachers usually take grammar, reading comprehension, writing and other parts as the focus, which leads to the neglect of English pronunciation teaching. Teachers only teach according to the requirements of the syllabus and rarely interact with students. As a foreign language, the lack of language environment is undoubtedly an important problem for Chinese students ( $\mathrm{Lu}, 2018$ ).

Considering that oral English is still at the disadvantage under the education system of China, many researchers have gave some feasible strategies of Oral English teaching. And they all have different ideals. For example, Lu concludes the methods in four aspects. (1) Pay attention to phonetic symbols throughout teaching (2). Practice frequently and use teaching materials flexibly (3).Create opportunities and strengthen practice (4) Timely correct errors and strengthen communication ( $\mathrm{Lu}, 2018)$.

\section{Limitations of the Previous Studies}

Although examination-oriented education is still dominant, spoken English has been paid more and more attention by more and more people. Relevant studies are emerging endlessly, but oral English in developing areas is still not well developed. There are not many relevant studies, and the limited researches about developing regions are mainly focus on English as a whole. There are few studies specifically focus on the development of oral English in developing regions and some researches are too general. Many studies are not the results of field investigation and related studies which only focus on the situation in Zhejiang Province are quite few. Thus, to some extent, they are not credible enough.

\section{E. Significance of the Present Studies}

Although the author's research only mainly focuses on Ningbo and Zhoushan in Zhejiang province, which has certain limitations. As a field survey, this scope is not small, and the research results have high credibility. The writer finds out the inadequacies of oral English teaching in developing areas through comparing with the developed region in Zhejiang province of oral English teaching and no predecessors have done such investigation before. The results can not only point out the inadequacies of oral English teaching in developing areas of Zhejiang province, but also provide guidance for the future teaching and provide reference experience for other relevant investigation in other provinces and regions.

\section{ReSEARCH Methodology}

\section{A. Research Questions}

This research is aimed to find out the differences of oral English teaching between Ningbo and Zhoushan, especially the critical inadequacies in Zhoushan, which partly represents developing areas in Zhejiang province. Specifically, this thesis is designed to find the answers in the following questions:

1. What's the differences of students' attitude and psychology between Ningbo and Zhushan? 
2. What's the differences of information technology means used in teaching between Ningbo and Zhoushan?

3. What's the differences of teachers' teaching level, ability and attitude to oral English between Ningbo and Zhoushan?

\section{B. Participants}

The author receives approximately 300 questionnaires, among which 200 are available and provide high-quality data for the survey. The students under investigation are mainly from New First-tier City or Four-tier City which can represent developed and developing areas respectively in Zhejiang province. Therein 40 students are from Zhoushan and 40 students are from Ningbo. In addition, all the 30 teachers under interview are from Ningbo or Zhoushan.

\section{Instruments}

There are two instruments used in this survey: questionnaire and interview. All the data collected are immensely useful and proffer information for the author to find the differences of students' attitude, psychology, education informatization, teachers' teaching level, ability and attitude to oral English teaching between Zhoushan and Ningbo in Zhejiang province.

Among all kinds of tools, questionnaire and interview are quite popular means to collect information. The questionnaire in the research are designed for students who studied in Zhejiang province, mainly in Zhoushan and Ningbo when they were in junior middle school. And all the questions are written in Chinese in case of misunderstanding and puzzles. The questions are mainly from the following three dimensions: students' attitude, psychology, ability of oral English and education informatization and teachers' teaching level, ability and attitude to oral English teaching. As for the detailed information, it is shown in Appendix One.

Apart from students, the teachers in junior middle school in Zhoushan and Ningbo are also the participants of this survey. With the interviews designed for them, the author collects available enough information about teachers' ability and attitude, which can absolutely assist the author in finding the critical factors affect students' ability of oral English. Though teachers all do well in English, the questions are all written in Chinese in order to make a easier communication and avoid misunderstanding. The specific questions are demonstrated in Appendix Two.

\section{RESUlTS AND DisCUSSION}

According to the collected data from the questionnaire, the author demonstrates the final results of the questionnaire done by students from junior middle school in Zhoushan and Ningbo and tries to analyze the influential factors of students per se, language environment and teachers. After analyzing the answers of the interview, the author manages to look out the connections between teachers and students' oral English level.

\section{A. The Results of the Survey}

After meticulous disposal and reorganization of the data, the analysis results of the questionnaire and questionnaire survey are as follows.

\section{The Results of the Questionnaire Survey}

Questions in the questionnaire are mainly divided into five parts and all the results are shown in a logical way.

(1). Students' opinions about oral English

There are only two questions concerned about nowadays the students' opinions about oral English from NIngbo and Zhoushan. We can easily find the answer in Q19 and Q23, which shows that most students attach the importance of oral English and agree that oral English should be pay enough heed to both from Ningbo and Zhoushan.

(2). The current different conditions between students from Ningbo and Zhoushan.

The author designs four related questions (question 12, question 20, question 21, and question 22) to find the current differences of ability or confidence about oral English between students in developed and developed areas in Zhejiang province. And the final results are shown as follows:

In Q12, 67.5\% students in Ningbo province choose more than two choices while only 32.5\% students in Zhoushan do that. In Q20 and Q22, most students reckon that the oral English teaching is basically satisfactory both in Ningbo and Zhoushan, but the percentage is slightly higher in Ningbo. As for Q21, students from Ningbo evaluate themselves higher than students from Zhoushan in their ability of oral English. By and large, these results partly shows the existing differences of students' master of phonetic knowledge and ability of oral English between developed areas and developing areas in Zhejiang province.

(3). The differences of influential factors of students per se including psychology and attitude.

The author designs five related questions (question2, question3, question4, question13, question18) to find the differences of influential factors of students per se in Ningbo and Zhoushan. The final results are demonstrated as follows:

In Q2, 18 students from Ningbo choose the third choice, namely, 45\% students studied English because of requirement of curriculum and examination. In Zhoushan, the percentage is even bigger, which is almost up to $80 \%$. In Q3 and Q4, students choose listening and writing more than reading and speaking in Zhoushan while the percentage of these choices differ slightly in Ningbo, which can definitely show the different attitudes towards oral English between 
these two groups of students. It is found in Q13 that most students were likely to pay attention to the pronunciation of words or sentences more or less whether they are from Ningbo or Zhoushan. Nevertheless, there are totally 22 students in Ningbo do these out of their own will, that is to say, more than half of the students have the awareness of practicing pronunciation. Compared with Ningbo, students in Zhoushan seem to lack consciousness of the importance of oral English as 70\% students take heed of pronunciation just in case of teachers' correct or criticism. As for the frequency of taking part in English speech contests, English debate contests etc, both students from Ningbo and Zhoushan rarely take part in these competitions. To some extent, it is mainly because of the low frequency of such kind of contest in their junior middle school, which we can find in Q17. Though more students in Ningbo have taken part in these competitions, the difference is almost negligible.

(4). The differences of language environment between Ningbo and Zhoushan.

The author designs four related questions(question 5, question 6, question 7, question 16 and question 17) to find the differences of language environment including educational theory about English and educational informalization between developed and developed areas in Zhejiang province. And the final results are shown as follows:

In Q5, we find more students from Zhoushan have attended extracurricular classes where they learn English grammar and do exercises. Though less students from Ningbo reinforce their English in a cram school, several students have take extracurricular classes about oral English, which is relatively considerable compared to Zhoushan. In Q6, it is found that more than two thirds students from Ningbo say they speak English more frequently in class and approximately $50 \%$ students from Zhoushan do so. Results are almost the same in Q7, which makes the author start to considerate the connection between these two. As for the educational informalization, we find there is no distinct difference of applying information technology means in teaching. Teachers from Ningbo or Zhoushan both use Power Point, video, recorder etc. to increase efficiency of class.

(5). The differences of influential factors of teachers' ability and attitude

There are two questions in the questionnaire about teachers' ability of oral English (Question 9, Question 10)and four about their attitude(Question 8, Question 11, Question 14, Question 15). According to these results, there are existing differences of teachers' ability and attitude between Ningbo and Zhoushan, which may immensely influence students' ability of oral English or the awareness of the importance. The results are as follows:

All the students are basically satisfactory with their teachers' oracy since no one choose the third or fourth choice in Question 9, though there is indeed a difference of teachers' English speaking skills between Ningbo and Zhoushan. Among all the 40 students from Ningbo, more than half of them reckon that their teachers oracy is excellent while only a quarter of the 40 students from Zhoushan choose the same choice. In Question 10, more than half students learn the pronunciation from their teachers whether they are from Ningbo or Zhoushan. As for the teachers' attitude towards oral English, some related information have been collected. It is found that teachers from Ningbo tend to use variable methods to teach the pronunciation while students from Zhoushan often learn the knowledge of phonetics and pronunciation through the daily exercises, which seems relatively monotonous when compared to Ningbo. There is an interesting phenomena the author find in Question 11. Almost all the students choose the third choice, namely, teachers all care much about grades whether they are from Ningbo or Zhoushan, which is beyond expectation since that percentage, as the author understand it, would not be so high, especially in Ningbo where oral English has been paid relatively more heed. In Q14, 60\% students from Ningbo say their teachers care more about grammar when students speaking English and the percentage in Zhoushan 12.5\% more than that in Ningbo. As for the homework about oral English, students choose the second choice most whether they are from Ningbo and Zhoushan. Nevertheless, 22.5\% students from Zhoushan say their English teachers don't assign such kind of homework and in Ningbo the percentage of this choice is lower, which is $12.5 \%$.

\section{The Results of the Interview Survey}

There are totally 13 questions in the interview survey. One question comes to the difference of the ability of oral English between students from Ningbo and Zhoushan. Two questions confer to the language environment. Seven questions are about the attitude of the teachers and three are concerning about their own ability.

In question 3, we find that teachers from have a higher evaluation of students' spoken language ability, which can also reflect to some extent that there is a certain difference in the spoken language ability of students from Ningbo and students from Zhoushan. In question 6, a total of 13 teachers from Ningbo state that they use English to teach most of the time in class while only 10 teachers from Zhoushan do so. In question 12, the answers of teachers from Ningbo and teachers from Zhoushan are basically the same. They all say that China's exam-oriented education has led to insufficient attention to spoken language. This is one of the most important reasons. Questions 1, 2, 4, 5, 10, 11, 13 all concern the degree of emphasis on spoken language by English teachers. It is found that whether it is teacher from Ningbo or from Zhoushan, most of them believe that the main purpose of junior high school students to learn English is to take entrance exams. Only three teachers from Ningbo and one teacher from Zhoushan think that the purpose is to allow students to master another language. However, in question 2, we find that all teachers agree that spoken English is of vital importance. The answer of question 4 also reflects that all teachers believe that oral communication in class is very necessary. However, of the 15 teachers from Zhoushan, only 9 teachers often conduct classroom oral communication, and 14 teachers in Ningbo stated that they often perform such activities. Regarding the professors of oral knowledge, most teachers from Ningbo say that they intersperse related phonetic knowledge in daily classes, and some teachers 
from Zhoushan believe that plosion, stress, and liaison are difficult for junior high school students. It is enough for them to know how to read and there is no need to know the reason. Certainly, all the teachers pay attention to the students' oral expressions, which can be seen from the answer to question 14. In question 13, 13 teachers from Ningbo and 10 teachers from Zhoushan choose to cultivate students' comprehensive application capabilities while the rest of the teachers paid more attention to the mastery of English grammar and knowledge. The lack of the language environment

As we all know, language learning needs an environment which helps learners form a language-learning habit and continuously get the input of language. However, English speaking isn't included in the classes of middle schools in underdeveloped area. Students would speak fluent Chinese and teachers would teach them almost in Chinese as if it were a Chinese lesson. After class, oral homework should have been an important part in language learning which could consolidate students' learning outcomes. But the statistics show that in middle school most students have little oral homework when they are in middle school as speaking is paid less attention to than other aspects of English learning. In addition, students don't have activities about English speaking which can train their pronunciation and give them a language environment. Therefore, the language environment is sorely lacking.

\section{B. The Current Situation of Oral English Teaching}

After meticulous analysis of the results of the questionnaire and interview, the author managed to find out the connections between students per se, language environment, teachers and students' oral English level. In addition, the main current situation of oral English teaching in Zhoushan and Ningbo has been known.

1. Discussion of the Differences of Oral English Teaching between Developed Areas and Developing Areas

According to the results of the questionnaire and interview, the author finds the differences of oral English teaching between Ningbo and Zhoushan. When it comes to students' opinions about oral English, the author finds that most students pay great attention to oral English, no matter where he is from. However, through the teachers' evaluation and students' self-evaluation, we find that there is indeed a gap of students' ability of oral English between Ningbo and Zhoushan. Compared with Zhoushan, Ningbo's environment urges students to pay more heed to oral English and learning oral English. Secondly, students from Ningbo seem to be more interested in oral English than students from Zhoushan. They also have a relatively high awareness of practicing oral English in their study. As for the educational informalization, we find there is no distinct difference of applying information technology means in teaching. Under the strong support and attention given by the country and Zhejiang government to education informatization, the construction of basic education informatization hardware, software and resources in Zhejiang has achieved extraordinary development, and the basic education informatization has achieved fruitful results. At present, technology and hardware equipment are not prominent problems for Zhejiang. Teachers from Ningbo or Zhoushan both use Power Point, video, recorder etc. to increase efficiency of class. However, teachers' ability and attitude have an essential role to play in students' oral English ability since it is found that teachers from Ningbo pay more attention to oral English than teachers from Zhoushan. What's more, their oral English ability are also relatively higher than teachers from Zhoushan.

\section{Discussion of the Critical Inadequacies in Developing Areas}

The main adequacy of Zhoushan is the teachers' teaching level, ability and attitude to oral English. Influenced by the region, excellent young English teachers prefer to stay in Ningbo, where the economy is relatively advanced. Therefore, Ningbo has a relatively strong English teaching force compared with Zhoushan. So the teachers' oral English level in Ningbo is relatively higher, which is more likely to have a correct and positive impact on students' oral English. In addition, influenced by economic development and the language environment, English teachers from Ningbo tend to pay more attention to oral English teaching while in Zhoushan, Junior middle school English teaching is more affected by exam-oriented education and English teachers generally focus on basic theoretical knowledge of English teaching, which lead the result that the written ability of students is much better than oral expression ability. Furthermore, the author reckons that students' attitude and importance attached to oral English are also influenced by teachers to a certain extent.

\section{Summary of Major Findings}

This research is aimed to find out the differences of oral English teaching between Ningbo and Zhoushan, especially the critical inadequacies in Zhoushan, which partly represents developing areas in Zhejiang province. Specifically, the answers of questions put up with in 3.1 have been found. There is difference of students' attitude and psychology between Ningbo and Zhushan, while no obvious difference of information technology means used in teaching between these two areas. And the main adequacy of Zhoushan is the teachers' teaching level, ability and attitude to oral English.

\section{CONCLUSION}

This research has studied the differences of junior high school students' oral English in Ningbo and Zhoushan by means of questionnaires and interviews respectively, and the author finds out the reasons for the differences between junior high school students' oral English in developed and underdeveloped areas of Zhejiang Province. Among them, English teachers play the most important role. The research provides a direction for improving junior high school students' oral English level in underdeveloped areas of Zhejiang Province in the future and also provides a reference for 
other similar researches of oral English.

\section{APPENDIX}

\section{浙江省大学生初中英语口语教学情况调查问卷}

您好! 这是一份无记名的有关浙江省大学生初中英语口语学习情况的问卷调查, 现在耽搁您几分钟时间, 对下面的问题进行选项回答。请根据您自己的情况如实填写。谢谢合作!

1. 你来自哪里? [单选题] *

○浙江杭州

○浙江丽水、嘚州

○浙江宁波

o浙江舟山

○其它

2. 初中时, 你喜欢英语的原因是什么? [单选题]*

○对外国文化感兴趣, 掌握语言及学习其文化

○能说一口流利的英语感觉很酷

○为了应试及找工作 宁波 $45 \% 18$ 人 舟山 $77.5 \% 31$ 人

3. 初中时, 你最喜欢英语的哪一部分? [单选题]*

○听力

○阅读

○口语

○写作

4. 若你在初中时有机会参加英语培训班, 你最想提高英语哪方面的能力? [单选题] *

听力

○阅读

○口语

○写作

5. 你在初中时有参加过课外英语培训班吗, 主要培训哪些方面? [单选题]*

○参加过, 包含听力口语, 写作语法等各方面训练

○参加过, 主要针对写作语法知识训练

○参加过, 主要针对听力口语训练

○没参加过

6. 在初中英语课堂中, 你说英语的机会多吗? [单选题] *

。不多, 多用中文

○多, 多用英文

○中英混杂, 中英文相差不多

○其它

7. 在初中英语课堂中, 你的英语老师如何授课? [单选题] *

○纯英文

○大部分是英文

○大部分是中文

○中英文混杂, 比例相当

○纯中文

8. 你的初中英语老师以哪些方式教发音? [多选题] *

口经常在课堂中教导及练习

口进行音标及其它方面的默写, 抽背, 单独纠正

口花一两节课教读后, 不再细细纠正

口常进行角色扮演或配音指导

口其它

9. 你觉得你的初中英语老师口语能力怎么样? [单选题] *

○非常好, 发音标准, 口语流利 宁波 55\% 舟山 $25 \%$

○较好, 发音基本正确 宁波 45\% 舟山 $75 \%$

○一般, 会有错误的发音

。很差, 口音重, 错误多 
10. 你觉得你初中英语老师的口语水平对你的影响大吗? [单选题] * ○很大, 发音基本都是跟着老师学

。不大, 自己会认音标, 或通过录音, 能知道正确发音

11. 在初中时, 你的英语老师更注重什么? [单选题] *

○语法习题及作业

○学生口语交际能力

○学生考试成绩

○其它

12.初中时你了解以下哪些语音知识? [多选题] *

口重读

口音标

口连读

口语音语调

口爆破

口都不了解

13. 初中时, 你在朗读英语过程中会注意上题所提及的语音知识吗? [单选题] *

。不会, 因为老师也不会刻意纠正

○会, 如果出错, 老师会进行纠正指导

。不会, 因为根本不了解

○会, 自己经常做这方面口语练习

14. 初中英语课堂上, 老师请同学朗读时会更注重什么? [单选题] *

○语法词汇正确性

○发音正确性、口语连贯性

15. 你的初中英语老师会布置口语相关作业吗? [单选题] *

。不会

○偶尔

○经常

16. 初中时, 老师会用到以下哪些设备或形式进行口语听力教学? [多选题]*

$\square$ Power Point

口录音机

口教材音频

口网络视频音频

其他

17. 你的初中是否常设有英语演讲、辩论等比赛或提供在公共场合进行英语口语表达的机会? [单选题] * 。偶尔，不多

○几乎没有

○经常有

18. 你是否经常参加英语演讲、辩论比赛或在公众场合进行英语口语表达? [单选题] * ○偶尔，不多

○几乎没有

○经常有

19. 现处于大学的你, 认为英语口语重要吗? [单选题]*

○不重要

○一般重要

○很重要

○其它

20. 如今身为大学生的你, 觉得当初初中学校的口语教学是否到位? [单选题] * ○十分到位

○基本到位

○不到位

21. 你觉得自己现在的英语口语能力如何? [单选题] *

○非常好

○中等偏上

○中等 
○中等偏下

很差

22. 学习了大学英语口语知识后, 你觉得初中所教授的口语知识是否有错误? [单选题] * ○有些地方相差很大

○完全没有

o类似, 相差不大

○不了解

23. 你觉得初中的英语口语教学是否应该得到重视? [单选题]*

○是, 口语能力比书面成绩重要

○否, 学好英语语法和词汇就够了

○是, 但英语语法和词汇比口语更加重要

○是, 口语能力和书面表达能力一样重要

\section{教师采访问卷}

1. 老师您认为初中学生学习英语的最大目的是什么?

2. 您认为初中学生会讲流利的英语重要吗?

3.您觉得班里的学生英语口语水平怎么样?

4. 您认为课堂上有无必要进行英语口语交际?

5. 您会在课堂上与学生进行口语交流吗?

6. 您上课的时候会用英文教学吗

7. 您对自己的口语水平有信心吗?

8. 您觉得您所在的初中或舟山（宁波）英语教师总体口语水平如何?

9. 您觉得自身的口语能力会对学生的口语能力产生影响吗?

10. 您是否会在课堂上教授口语知识, 如连读, 爆破, 重音等?

11. 您是否会注意学生的发音, 语调和重音?

12. 您觉得初中英语口语教学存在最大的障碍是什么?

13. 您在教授英语时更加偏重语法词汇等知识点 还是学生的综合英语应用能力?

\section{REFERENCES}

[1] Bai, Y. Bai, J. (2012). Application of Multimedia Technology in Spoken English Teaching in Vocational Middle Schools in Underdeveloped Areas. Western China Technology, 6, 89+84.

[2] Cai, L. (2016). A Study on the Influence of Question on the Oral Output of Students in Junior English Teachers. Lu Dong University.

[3] Chen, H. (2016). An Analysis of the Performance of Compulsory Education Funding in Economic Underdeveloped Areas and Its Countermeasures. Central China Normal University.

[4] Gary, P. (2002). Effective Teaching Methods. Jiangsu: Jiangsu Education Publishing House.

[5] Lu, Y. (2018). Probing into the Problems and Countermeasures in English Speech Teaching in Junior High School, Liaoning Education, 5,73-75.

[6] Rachel H. (2010). Talking to learn and learning to talk: teacher and learner talk in the secondary foreign languages classroom. https://www.academia.edu/7210797/Talking_to_learn_and_learning_to_talk_teacher_and_learner_talk_in_the_secondary_forei gn_languages_classroom. (accessed 26/12/2019).

[7] Zhan, Q. (2017). Strategies for Improving the Effect of English Teaching in Underdeveloped Areas, Primary School Teaching Reference, 21,39-40.

[8] Zhang, X. (2016). A Study on the Construction of Teachers in Rural Compulsory Education in Underdeveloped Areas, Yan'an University.

[9] Zhou, Z. (2008). Research on the Status Quo of English Oral Ability Cultivation in Urban Junior High Schools in Underdeveloped Areas and Countermeasures, Journal of Guangxi Teachers Education University(Philosophy and Social Sciences Edition) , 1, 44-46.

Wei Xiong was born in Shanghai, China in 1998. She is a grade three student at Zhejiang Ocean University, China, majoring in English. 